Fifth International Conference on Sustainable Construction Materials and

Technologies. http://www.claisse.info/Proceedings.htm

\title{
RECYCLING OF SINGLE-STREAM WASTE GLASS IN FLOWABLE FILL
}

\author{
Pranshoo Solanki ${ }^{1}$, Thomas Bierma ${ }^{2}$, and Guang $\mathrm{Jin}^{3}$ \\ ${ }^{1}$ Associate Professor, Construction Management Program, Department of Technology, \\ College of Applied Science and Technology, Illinois State University, Campus Box \\ 5100, Normal, IL 61790, USA, psolanki@ilstu.edu (Corresponding Author) \\ ${ }^{2}$ Research Professor, Department of Health Sciences, Illinois State University, Normal, \\ IL 6170, USA, tbierma@ilstu.edu \\ ${ }^{3}$ Professor, Department of Health Sciences, Illinois State University, Normal, IL 6170, \\ USA, gjin@ilstu.edu
}

\begin{abstract}
Glass is often a byproduct of many municipal recycling programs. However, glass collected through the local single-stream recycling system represents a significant financial burden on the program due to lack of a market for mixed glass. Therefore, the aim of this study was to evaluate the feasibility of utilizing recycled glass as a substitute for cement and fly ash in flowable fill. An attempt was made to clean and crush singlestream waste glass which indicated that desired gradation can be achieved. Further, ten mixtures of flowable fill were prepared by using different proportions of finer and coarser portion of glass powder as a fly ash substitute in flowable fill. Each mixture was tested for flowability and cylindrical specimens were prepared by using split molds fabricated in the laboratory. Flow consistency results indicated that waste glass powder can be used as a suitable replacement of fly ash in flowable fill. Compressive strength results showed improvement with increase in finer portion of the glass powder. More research is required for determining optimum percentage and size of waste glass powder which can be used to achieve required minimum strength of flowable fill.
\end{abstract}

Keywords: flowable fill, glass, flowability, strength, single-stream waste, recycling

\section{INTRODUCTION}

Cement has a pivotal role in the construction industry (Davidovits, 1994). However, cement is one of the key contributors to global $\mathrm{CO}_{2}$ emission levels. This is due to the energy-intensive nature of cement production processes (Celik et al., 2014). According to US Environmental Protection Agency report (USEPA, 2017), $\mathrm{CO}_{2}$ emissions in 2015 from cement production in the US were estimated to be 39.9 million metric tons (MMT) which is fifth largest source of $\mathrm{CO}_{2}$; total $\mathrm{CO}_{2}$ emission was $5411 \mathrm{MMT}$ which is $82.2 \%$ of total greenhouse gases. The cement manufacturing process also use fossil fuels which constitute additional combustion related $\mathrm{CO}_{2}$ emissions (Gibbs et al. 2000).

One of the $\mathrm{CO}_{2}$ emission abatement technology is the use of supplementary cementitious materials (SCMs) to offset a portion of the cement for reducing the environmental impact from the industry. Several industrial by-products have been used 
successfully as SCMs, including, fly ash, silica fume and ground granulated blast furnace slag (Hanle et al., 2004; Rehan and Nehdi, 2005; Ali et al., 2011; Imbabi et al. 2012). Another material which has potential as SCM, however, not yet achieved the same commercial success is recycled glass (Islam et al., 2017). Consequently, the aim of this study was to evaluate the feasibility of utilizing recycled glass as a substitute for cement and fly ash in flowable fill.

\section{LITERATURE REVIEW}

Previous studies show that glass can be used as an aggregate replacement (base for roadwork, structural fill, pipe bedding, and concrete mixtures) or cement replacement or both (Bazant et al., 2000; Byars et al., 2004; Topcu and Canbaz, 2004; Shi et al., 2004; Shayan and Xu, 2006; Jani and Hogland, 2014; Islam et al. 2017). For example, Arulrajah et al. (2016) studied use of recycled glass in pipe bedding. Multiple studies showed use of recycled glass in asphalt and concrete. Peyvandi et al. (2013) conducted research for evaluating feasibility of partially replacing cement with $20 \%$ by weight pulverized glass $(<15 \mu \mathrm{m})$. Though the sodium oxide content in mixed color waste glass is relatively high, its high reactivity allows it to help mitigate the potential for alkali-silica reactions. This study observed that Portland cement and milled glass has significantly lower expansion than a control mixture with Portland cement alone (Peyvandi et al., 2013).

Many studies have been conducted on the use of recycled glass as a partial replacement for fine aggregate in self-compacting concrete (SCC) over the past few years. For example, Ali and Al-Tersawy (2012) conducted a study of 18 concrete mixes that replaced traditional fine aggregate in proportions of $0 \%, 10 \%, 20 \%, 30 \%, 40 \%$, and $50 \%$ with recycled glass (which may include container glass, flat glass, bulb glass, and cathode ray tube glass). The results showed that slump flow increased with the increase of recycled glass content. On the other hand, mechanical properties such as the compressive strength, splitting tensile strength, flexural strength and static modulus of elasticity values of recycled glass containing SCC mixtures decreased with the increase of percentage of recycled glass. It was concluded that recycled glass as fine aggregate can be successfully incorporated in SCC (Ali \& Al-Tersawy, 2012).

BASF's FILTERPAVE division developed sustainable pavement products that utilized waste glass on a commercial scale (BASF, 2017). FILTERPAVE Glass Series and Stone Series contain $40 \%$ and $20 \%$ post-consumer recycled glass respectively. This product was designed for pedestrian and light vehicle traffic loads. This product not only uses landfilled materials, it helps gain LEED credits. It helps reduce stormwater runoff and heat island effect.

It is also important to understand the standard for using waste glass as a construction material and to study the processes of cleaning glass to meet industry standards. The US Department of Transportation (USDOT, 2016) Federal Highway Administration reported the potential and acceptable use of waste glass as aggregate in asphalt mix and 
granular base. This report also provided guidelines for the gradation requirements of waste glass along with physical and chemical properties. For both asphalt concrete and granular base, guidelines required waste glass free of ferrous/nonferrous metals, plastic and paper. However, asphalt concrete mix designs limit glass to be 10 to $15 \%$ of the mix. For granular base, levels of debris in the waste glass should be limited to $5 \%$ as determined by the American Geophysical Institute (AGI) test method. Crushing and screening are required by US DOT (2016) for asphalt concrete mixes to eliminate flat and elongated particles. Waste glass should be crushed and screened to meet the requirements of a fine aggregate for using in granular base.

In addition, Chesner (1988) stated a solution for extracting the useful glass. He suggested that successful production of glass aggregate can be done using recycled asphalt pavement processing equipment such as crushers and screens. In addition, magnetic separation and air classification may also be required to remove any residual ferrous materials or paper still mixed in with the cullet (Chesner, 1988).

On the other hand, few studies suggested some negative effects of using glass in pavements. The Clean Washington Center (1993) report stated that recycled glass pavement tends to retain more heat. Additionally, this study found that increased amounts of glass in road surfaces could be desirable for visibility, however, at a certain ratio, the pavement will be too reflective and pose as a danger to drivers.

However, glass is in theory pozzolanic or even cementitious in nature due to relatively large quantities of silicon and calcium. Using glass as a cement component adds more to its value and allows the energy previously imparted to it during the glassmaking process to be exploited (Dyer and Dhir, 2001). Further, it will provide new market potential and greater likelihood for recycling by consuming the bulk of waste glass and reduce the amount of waste entering landfills.

\section{SINGLE-STREAM WASTE GLASS}

Glass is often a byproduct of many municipal recycling programs (Shi and Zheng, 2007; Tao, 2017). However, glass collected through the local single-stream recycling system represents a significant financial burden to the program due to lack of a market for mixed glass. Materials recovery facilities (MRFs) must ship the mixed glass to sorting facilities where it is cleaned and separated by color. The high cost of transportation and sorting fees affect local MRFs, resulting in numerous facilities no longer accepting glass. According to Environmental Protection Agency (EPA), 11.5 million tons of glass waste was generated in the US in 2014 and only $26 \%$ was recycled (approximately 3 million tons). In the State of Ohio, only approximately $22 \%$ of container glasses were recycled in 2015 (Tao, 2017). According to Shi and Zheng (2007), New York City annually collects more than 100,000 tons of glass and pays MRF's up to $\$ 45$ per ton for the disposal of the glass containing metals and plastics. Waste glass could also be recycled in glass manufacture which reduces energy consumption and raw materials use. However, not all glass waste can be recycled into 
new glass because of impurities, cost or mixed colors (Shi and Zheng, 2007). There is a need to develop markets for mixed waste glasses.

At local level in the State of Illinois, recycling generates approximately 360 tons per month of mixed glass debris in Bloomington-Normal, Illinois area alone. Out of 360 tons, approximately 60 tons is debris and approximately 300 tons is glass of various colors. This mixed glass is heavily polluted with debris containing shredded paper, glue residue and other materials which requires extra costs for cleaning (Figure 1 a). To understand the properties of waste glass coming out of MRF, sieve analysis was conducted in accordance with ASTM C136 test method on following three samples of waste glass: uncleaned uncrushed raw sample, cleaned uncrushed sample, and cleaned crushed sample. Samples were cleaned with water to remove floating debris and percent debris removed was calculated. Further crushed glass sample was obtained by placing cleaned glass in a five-gallon bucket and crushing the glass with a sledge hammer for approximately 15 minutes. Then, cleaned crushed sample was sieved and a photographic view of sieved portions are shown in Figure 1 (b).

Sieve analysis test results are presented in Figure 2. Each data point in Figure 2 shows an average value of two tests. It is important to note that sieve sizes were selected based on recommendation by Illinois Department of Transportation (IDOT, 2016) for flowable fill fine aggregates, i.e., fine aggregate No. 1 gradation (FA-1). Figure 2 shows the IDOT gradation specifications; upper limit (UL) gradation has more fines compared with those of lower limit (LL) gradation. It is evident from Figure 2 that uncleaned uncrushed glass is very coarse compared to the IDOT FA-1 requirements for flowable fill. Further glass was cleaned and approximately $21.4 \%$ of debris was removed. Sieve analysis tests results of cleaned uncrushed glass showed increase in coarse content. Cleaned crushed glass showed improvement in the finer content of the glass but still it was not within the gradation requirements of IDOT. Additional crushing was needed to meet IDOT specifications which is obtainable but labor intensive unless a milling equipment is used. 


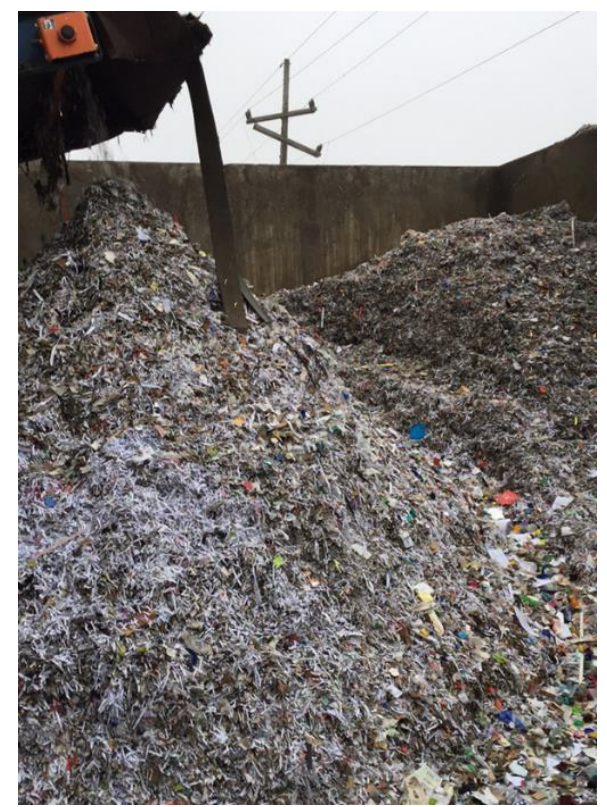

(a)
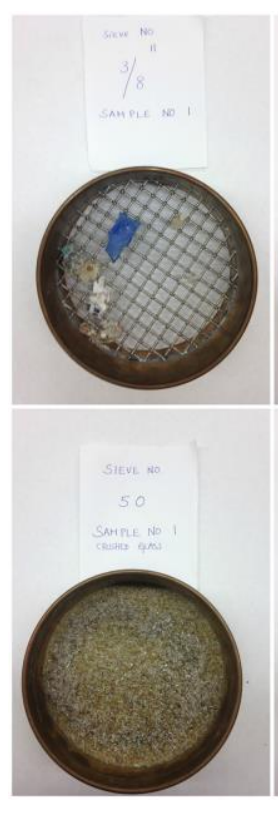

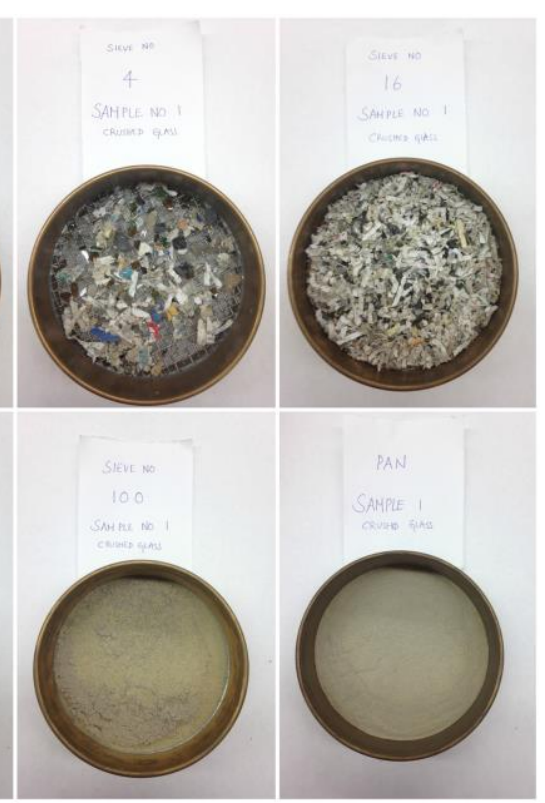

(b)

Figure 1 (a). Stockpile of waste glass at local MRF; (b) Sieved portions of cleaned crushed waste glass obtained from local MRF

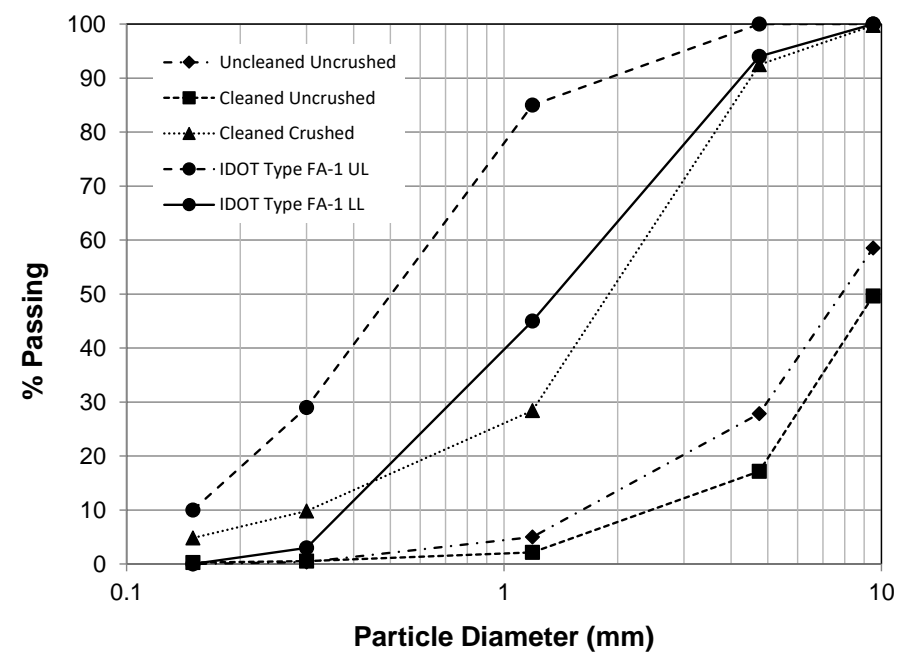

Figure 2. Sieve analysis results

\section{METHODOLOGY AND EXPERIMENTAL DESIGN}

\section{Material Types and Sources}

As noted in the previous section, crushing recycled glass is labor intensive. Also, research team had no access to milling equipment, therefore, it was decided to purchase ground glass from Vitro Minerals located in Jackson, Tennessee. A total of two types of glass, namely, ACAS glass pozzolans and glass concrete sand (CS-30) were used in this study (Figures 3a-b). ACAS glass (called as finer glass in this study) is made from post-consumer bottle glass collected from MRFs that is processed into a clean off-white 
powder with a minimum fineness of $90 \%$ passing US Sieve No. $325(<0.044 \mathrm{~mm}$, i.e., $44 \mu \mathrm{m}$ ). CS-30 glass (called as coarser glass in this study) is fine aggregate material made with uniform grain size distribution from $100 \%$ recycled bottle glass. Size range of CS-30 is 0.21 to $0.60 \mathrm{~mm}$ with minimum fineness of $98 \%$ passing US Sieve No. 30 $(<0.600 \mathrm{~mm}$, i.e., $600 \mu \mathrm{m})$. Level of contamination in these two glass samples were analyzed using Loss on Ignition (LOI) technique according to ASTM D7348. Level of contamination were found to be less than $0.01 \%$ for both glass samples. Virgin fine aggregates, Portland cement Type 1 and class $\mathrm{C}$ fly ash were collected from a local ready-mix concrete plant (Prairie Materials located in Normal, Illinois).

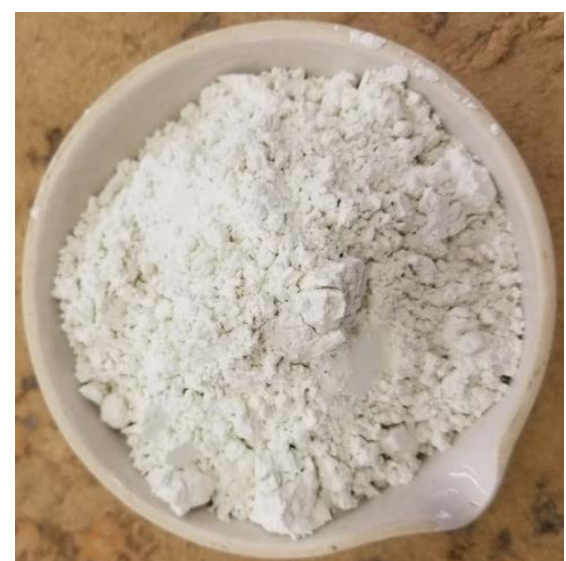

(a)

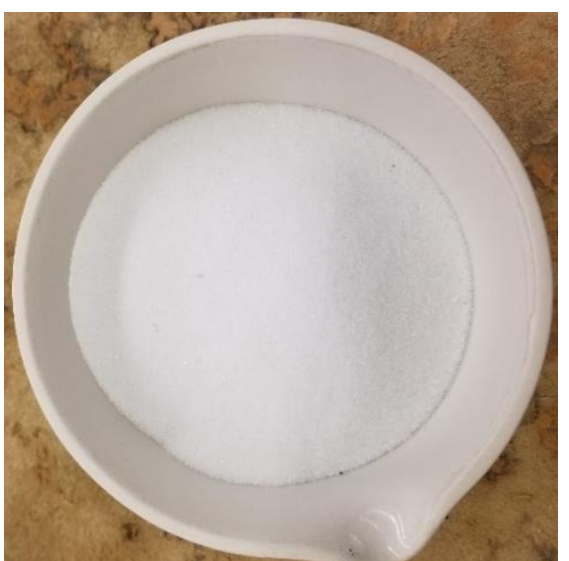

(b)

Figure 3. (a) ACAS glass powder; and (b) CS-30 glass sand

\section{Mix Design}

A total of ten flowable fill mixtures containing different fly ash, finer glass (ACAS) and coarser glass (CS-30) powder were prepared in this study. Table 1 shows the tentative proportions of all flowable fill mixtures that were considered in this study; proportion of each ingredient was selected in accordance with Illinois Department of Transportation (IDOT, 2016) specifications for flowable fill Mix\#1. The exact amount of water was decided based on the flow consistency of mix in accordance with ACI 229R (2013) recommendations; ACI 229R (2013) provides a procedure for designing flowable fill mixtures. One control mixture was prepared by mixing only Portland cement, fly ash, fine aggregates (i.e., sand) and water (no recycled glass). All remaining nine mixtures were divided into three groups (three mixtures in each group) prepared by substituting $25 \%, 50 \%$ and $100 \%$ of fly ash with recycled glass by weight (called as percent glass substitution, PG). Further each group consisted of three mixtures prepared by using finer ACAS glass percentage (\% by weight of total recycled glass) of $25 \%$, $50 \%$, and $100 \%$, to investigate the effect of ratio of finer ACAS and coarser CS-30 glass on the flowable fill mix performance.

\section{Specimen Preparation and Testing}

All ten mixtures were prepared by adding required amount of dry ingredients in a concrete mixer and mixing for 10 minutes. After preparation of mixtures, the flow consistency of mixtures was evaluated by conducting flow test in accordance with 
ASTM D6103 test method. To evaluate the strength of flowable fill mixes, the unconfined compressive strength (UCS) was measured after 28 days of curing. The strength test was performed using cylindrical specimens of $101.6 \mathrm{~mm}$ by $203.2 \mathrm{~mm}$ size (4 in. $x 8$ which were cast and cured following ASTM D4832 test method. Due to the low strength of flowable fill specimens, the plastic cylindrical molds used for specimen casting were specially fabricated in the laboratory for easy demolding (Figure 4a). The plastic pipe molds were pre-cut on two opposite sides, and then restored to their original shape by sealing them with steel strap and screws as shown in Figure 4 (a). Three molds were tied to a plywood board for easy handling and transportation after casting specimens out of each mix (Figure 4b). The wet flowable fill mix was cast into the molds, and finished using a tamping rod. After finishing, the specimens were covered with plastic wrap and cured for four days. On the fourth day, split molds were demolded after removing steel straps and specimens were placed in plastic storage box at a temperature of approximately $21^{\circ} \mathrm{C}\left(70^{\circ} \mathrm{F}\right)$ and high humidity environment $(>95 \%$ relative humidity) until the time of testing (Figure $4 \mathrm{c}$ ). Then, specimens were tested for compressive strength after 28 days of curing in accordance with ASTM D4832 test method. Three replicates were tested at each time to determine their peak loads and stress-strain responses using a displacement control testing machine operated at a rate such that the cylinder failed in not less than 2 minutes. The load and the displacement were recorded during testing using an automated data acquisition system. The unconfined compressive strength of specimens was calculated by dividing the peak load by the cross-sectional area of the cylinder.

Table 1. Design of flowable fill mix proportions

\begin{tabular}{|c|c|c|c|c|c|c|c|c|c|c|c|c|}
\hline Mix\# & Tag & $\begin{array}{c}\text { Cement } \\
\text { (lbs) }\end{array}$ & $\begin{array}{c}\text { Fine } \\
\text { Aggreg } \\
\text { ate } \\
\text { (lbs) }\end{array}$ & $\begin{array}{c}\text { Approxi } \\
\text { mate } \\
\text { Water } \\
\text { (lbs) }\end{array}$ & $\begin{array}{l}\text { Fly } \\
\text { Ash } \\
\text { (lbs) }\end{array}$ & $\begin{array}{c}\text { Percent } \\
\text { Glass } \\
\text { Substitution } \\
\text { (\% of Fly } \\
\text { Ash) }\end{array}$ & $\begin{array}{c}\text { Total } \\
\text { Recycled } \\
\text { Glass } \\
\text { (lbs) }\end{array}$ & $\begin{array}{c}\text { Finer } \\
\text { ACAS } \\
\text { Glass } \\
\text { Percenta } \\
\text { ge }^{1}\end{array}$ & $\begin{array}{c}\text { Finer } \\
\text { ACAS } \\
\text { Glass } \\
\text { (lbs) }\end{array}$ & $\begin{array}{c}\text { Coarser } \\
\text { CS-30 } \\
\text { Glass } \\
\text { (lbs) }\end{array}$ & $\begin{array}{l}\text { Numbe } \\
r \text { of } \\
\text { sample } \\
s\end{array}$ & $\begin{array}{l}\text { Curing } \\
\text { Period } \\
\text { (days) }\end{array}$ \\
\hline 1 & Control & \multirow{10}{*}{0.37} & \multirow{10}{*}{21.64} & \multirow{10}{*}{4.04} & 0.93 & 0 & 0.00 & 0 & 0.00 & 0.00 & 3 & 28 \\
\hline 2 & PG-25 ACAS-25 CS30-75 & & & & 0.70 & 25 & 0.23 & 25 & 0.06 & 0.17 & 3 & 28 \\
\hline 3 & PG-25 ACAS-50 CS30-50 & & & & 0.70 & 25 & 0.23 & 50 & 0.12 & 0.12 & 3 & 28 \\
\hline 4 & PG-25 ACAS- 100 CS30-0 & & & & 0.70 & 25 & 0.23 & 100 & 0.23 & 0.00 & 3 & 28 \\
\hline 5 & PG-50 ACAS-25 CS30-75 & & & & 0.47 & 50 & 0.47 & 25 & 0.12 & 0.35 & 3 & 28 \\
\hline 6 & PG-50 ACAS-50 CS30-50 & & & & 0.47 & 50 & 0.47 & 50 & 0.23 & 0.23 & 3 & 28 \\
\hline 7 & PG-50 ACAS-100 CS30-0 & & & & 0.47 & 50 & 0.47 & 100 & 0.47 & 0.00 & 3 & 28 \\
\hline 8 & PG-100 ACAS-25 CS30-75 & & & & 0.00 & 100 & 0.93 & 25 & 0.23 & 0.70 & 3 & 28 \\
\hline 9 & PG-100 ACAS-50 CS30-50 & & & & 0.00 & 100 & 0.93 & 50 & 0.47 & 0.47 & 3 & 28 \\
\hline 10 & PG-100 ACAS-100 CS30-0 & & & & 0.00 & 100 & 0.93 & 100 & 0.93 & 0.00 & 3 & 28 \\
\hline
\end{tabular}

${ }^{1}$ Finer glass percentage is determined by weight of finer ACAS glass powder divided by total weight of glass powder 


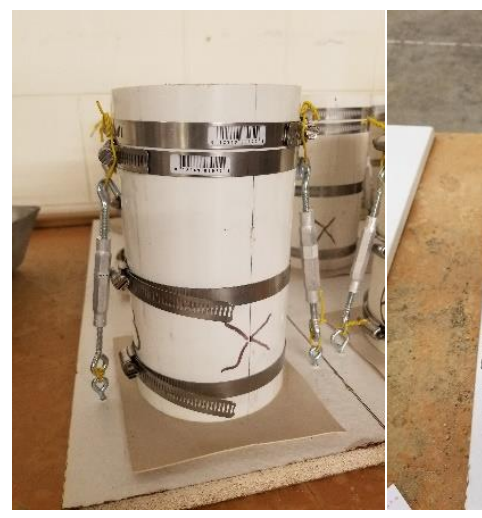

(a)

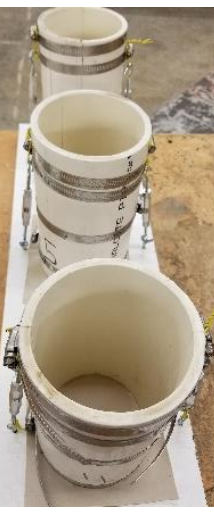

(b)

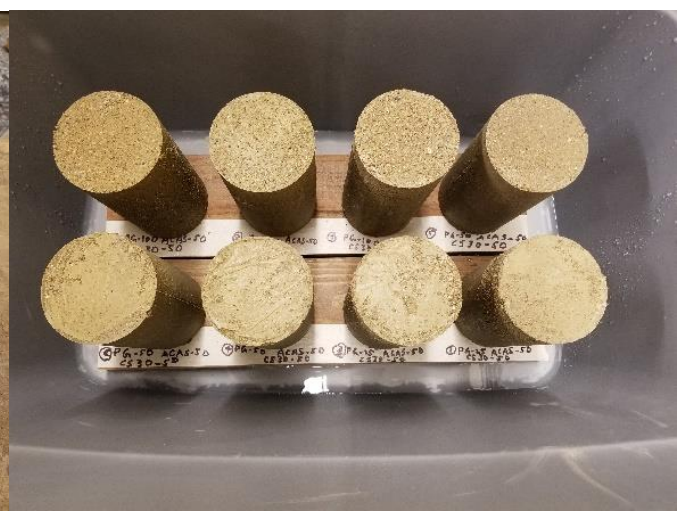

(c)

Figure 4 (a) Specimen mold; (b) Three molds tied to a plywood board; and (c) Specimens in a box under curing

\section{RESULTS AND DISCUSSION}

Results of all ten mixtures tested in this study are presented in Table 2. Each compressive strength test result is average of three tests conducted on three specimens. Further results are discussed in subsequent sections.

Table 2. Flow consistency and compressive strength test results

\begin{tabular}{|c|c|c|c|c|c|c|c|}
\hline Mix\# & Tag & $\begin{array}{c}\text { Percent } \\
\text { Glass } \\
\text { Substituti } \\
\text { on (\% of } \\
\text { Fly Ash) }\end{array}$ & $\begin{array}{c}\text { Finer } \\
\text { ACAS } \\
\text { Glass } \\
\text { Percenta } \\
\text { ge }\end{array}$ & $\begin{array}{l}\text { Spread } \\
\text { (in) }\end{array}$ & $\begin{array}{c}\text { Spread } \\
(\mathrm{cm})\end{array}$ & $\begin{array}{l}\text { Compressi } \\
\text { ve Strength } \\
\text { (psi) }\end{array}$ & $\begin{array}{l}\text { Compress } \\
\text { ive } \\
\text { Strength } \\
(\mathrm{kPa})\end{array}$ \\
\hline 1 & Control & 0 & 0 & 9.50 & 24.1 & 17.3 & 119 \\
\hline 2 & PG-25 ACAS-25 CS30-75 & 25 & 25 & 8.50 & 21.6 & 9.9 & 68 \\
\hline 3 & PG-25 ACAS-50 CS30-50 & 25 & 50 & 8.50 & 21.6 & 16.0 & 110 \\
\hline 4 & PG-25 ACAS-100 CS30-0 & 25 & 100 & 13.00 & 33.0 & 20.1 & 138 \\
\hline 5 & PG-50 ACAS-25 CS30-75 & 50 & 25 & 10.00 & 25.4 & 10.2 & 70 \\
\hline 6 & PG-50 ACAS-50 CS30-50 & 50 & 50 & 13.50 & 34.3 & 18.5 & 127 \\
\hline 7 & PG-50 ACAS-100 CS30-0 & 50 & 100 & 13.25 & 33.7 & 20.3 & 140 \\
\hline 8 & PG-100 ACAS-25 CS30-75 & 100 & 25 & 11.00 & 27.9 & 9.3 & 64 \\
\hline 9 & PG-100 ACAS-50 CS30-50 & 100 & 50 & 9.00 & 22.9 & 18.4 & 127 \\
\hline 10 & PG-100 ACAS-100 CS30-0 & 100 & 100 & 6.50 & 16.5 & 28.0 & 193 \\
\hline
\end{tabular}

\section{Flow Consistency}

Variation of flow consistency with percent glass substitution and finer ACAS glass percentage is graphically presented in Figure 5. 


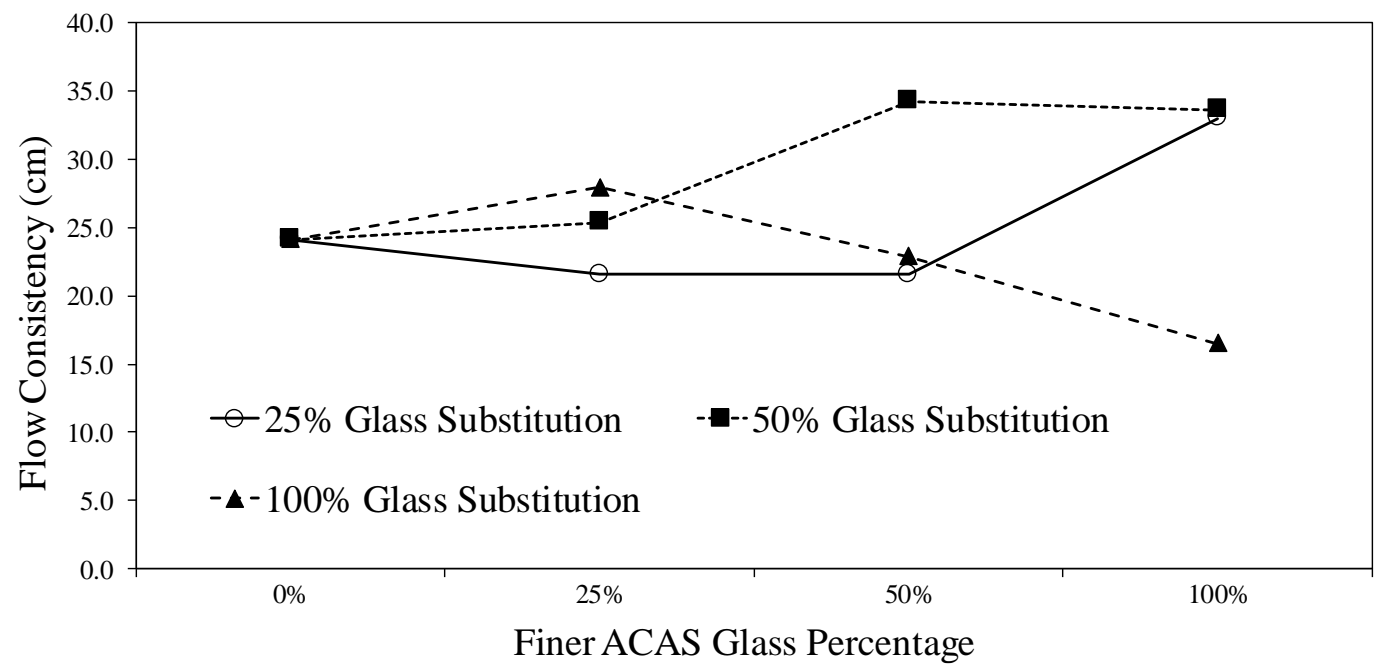

Figure 5. Variation of flow consistency with percent glass substitution and finer ACAS glass percentage

Effect of Percent Glass Substitution - It is evident from Figure 5 that at same finer ACAS glass percentage, increase in percent glass substitution from 25\% to 50\% increased flow consistency. For example, at 50\% finer ACAS glass content, flow consistency increased from $21.6 \mathrm{~cm}$ ( $8.5 \mathrm{in}$.) to $34.3 \mathrm{~cm}$ (13.25 in.). On the contrary, increase in percent glass substitution from 50\% to $100 \%$ resulted in increase in flow consistency at a finer ACAS glass percentage of $25 \%$ and decrease in flow consistency at finer ACAS glass percentage of $50 \%$ and $100 \%$.

Effect of Finer ACAS Glass Percentage - In general, introducing more finer ACAS glass showed improvement in flow consistency for $25 \%$ and $50 \%$ glass substitution. Mixes prepared by using $100 \%$ glass substitution showed decrease in flow consistency with increase in finer ACAS glass content.

All mixtures tested in this study except Mix\#10 (Table 2) showed a flow consistency of greater than $17.8 \mathrm{~cm}$ (7 in.), as required by IDOT (2016) specification for flowable fills. Few studies reported no change in workability (or flow) of concrete with inclusion of glass powder as cement replacement (Taha and Nounu, 2008; Wang et al., 2014). However, some studies concluded reduction in workability with replacement of cement with glass powder concrete or mortar mixtures (Metwally, 2007; Shao et al., 2000). Angular shapes and high specific surface area of glass particles harm the workability of concrete and mortar mixtures (Metwally, 2007; Shao et al., 2000). On the contrary, in a recent study by Islam et al. (2017), workability was found to increase with increase in percent (from 0 to $25 \%$ ) of cement replacement by glass powder in concrete specimens.

\section{Compressive Strength}

Variation of compressive strength with percent glass substitution and finer ACAS glass percentage is graphically presented in Figure 6. 


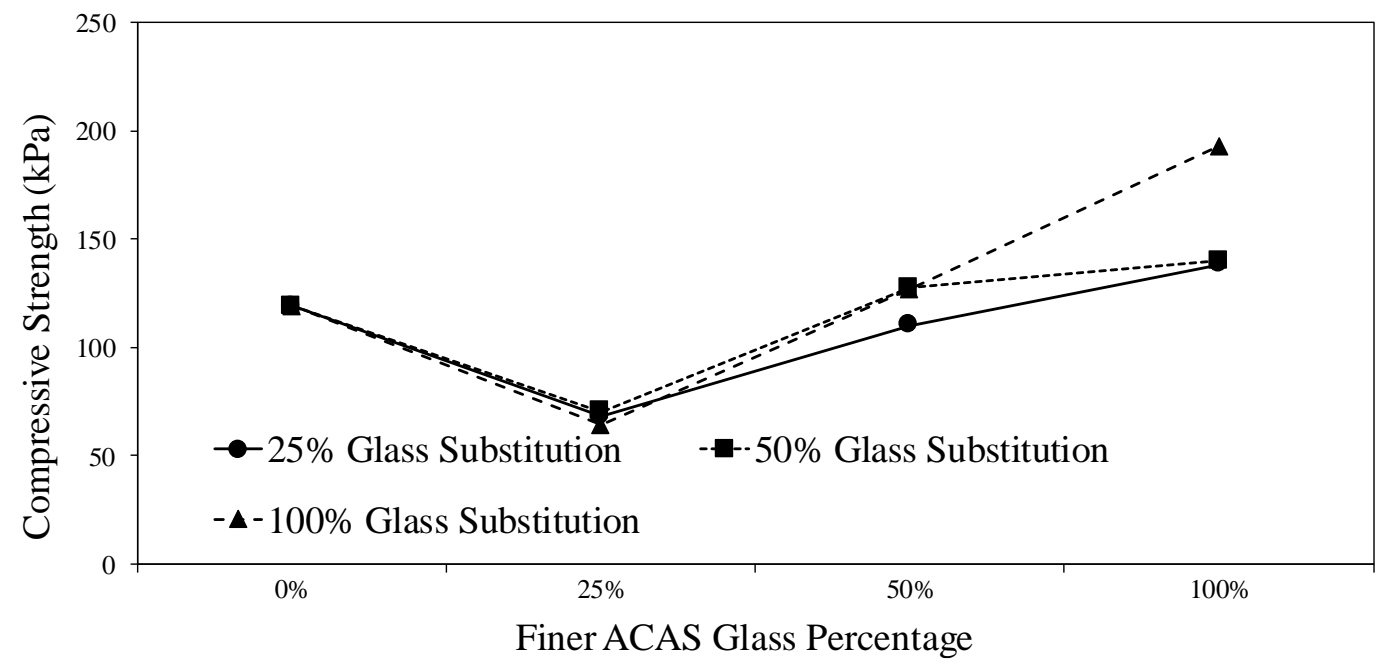

Figure 6. Variation of compressive strength with percent glass substitution and finer ACAS glass percentage

Effect of Percent Glass Substitution - Strength showed insignificant improvement with increase in percent glass substitution up to finer ACAS glass percentage of 50\%. At $100 \%$ ACAS glass content, increase in percent glass substitution from $25 \%$ to $100 \%$ showed significant improvement (from $138 \mathrm{kPa}(20.1 \mathrm{psi}$ ) to $193 \mathrm{kPa}(28.0 \mathrm{psi})$ ); an increase in strength by approximately $39 \%$.

Effect of Finer ACAS Glass Percentage - It is evident from Figure 6 that increase in finer ACAS glass percentage improved compressive strength of flowable fill specimens. For example, at a $100 \%$ glass substitution level, increase in finer ACAS glass percentage from $25 \%$ to $100 \%$ increased compressive strength from $64 \mathrm{kPa}(9.3$ psi) to $193 \mathrm{kPa}$ (28.0 psi); an increase in strength by approximately $201 \%$.

Several studies found improvement in compressive strength of concrete specimens with the substitution of cement with glass powder (Idir et al., 2011; Pereira-de-Oliveira et al., 2012; Shao and Leboux, 2001; Shao et al., 2000). Shao et al. (2000) studied the effect of the particle size of the waste glass powder as a $30 \%$ of cement substitute in concrete. Results showed increase in compressive strength of concrete with decrease in glass particle size from $150 \mu \mathrm{m}$ to $38 \mu \mathrm{m}$. These findings are consistent with the findings observed in this study. IDOT (2016) recommends a minimum and maximum 28 days compressive strength $207 \mathrm{kPa}$ (30 psi) and $1034 \mathrm{kPa}(150 \mathrm{psi})$, respectively, for flowable fill. However, no specimen in this study was able to achieve IDOT specified minimum strength.

\section{CONCLUSIONS AND RECOMMENDATIONS}

Based on the results presented in this study following conclusions could be drawn:

1) Single-stream waste glass could be cleaned and crushed to obtain desired gradation. However, crushing single-stream waste glass is labor intensive and milling equipment is recommended for crushing. 
2) Based on flow consistency results, waste glass powder has the potential to be a suitable replacement of cementitious material in flowable fill. However, consistency flow were found to be dependent on time of mixing and amount of water. Therefore, proper mixing and control of water in flowable fill containing waste glass is recommended.

3) Compressive strength was found to improve with increase in finer portion of the glass powder, i.e., ACAS glass percentage. The finer ACAS glass percentage of $50 \%$ or more is recommended to achieve strength greater than control specimens. Substitution of fly ash with $100 \%$ finer ACAS glass produced maximum strength of flowable fill specimens. However, additional study is needed to find the optimum percentage and size of waste glass which can be used to achieve strength level recommended by specifications.

\section{ACKNOWLEDGMENTS}

This work was supported by Environmental Protection Agency (EPA) P3 Award No. SU-83946901-0. The material collection assistance provided by Prairie Material, Midwest Fiber Inc. and Vitro Minerals is gratefully acknowledged. Also, authors would like to acknowledge students, namely, Samikaran Bhattarai, Jose Rodriguez, Michael Boffa and Cory Muehlfelt who assisted in the specimen preparation and testing.

\section{REFERENCES}

1. ACI 229R (2013). Report on Controlled Low-Strength Materials, American Concrete Institute, Farmington Hills, MI.

2. Ali, E. E., \& Al-Tersawy, S. H. (2012). Recycled glass as a partial replacement for fine aggregate in self-compacting concrete. Construction and Building Materials, $35,785-791$.

3. Arulrajah, A., Yaghoubi, E., Imteaz, M. and Horpibulsuk, S. (2016). Recycled waste foundry sand as a sustainable subgrade fill and pipe-bedding construction material: Engineering and environmental evaluation. Sustainable Cities and Society, 28, 343-349.

4. BASF (2017), Attractive Porous Paving for Stormwater Management, http://filterpave.net/about, Accessed on April 20, 2017.

5. Bazant, Z. P., Zi, G. and Meyer, C. (2000), Fracture mechanics of ASR in concretes with waste glass particles of different sizes, Journal of Engineering Mechanics, 126, 226-232.

6. Byars, E. A., Morales-Hernandez, B., \& Zhu, H. Y. (2004). Waste glass as concrete aggregate and pozzolan. Concrete, London, 38(1), 41-44.

7. Celik, K., Jackson, M. D., Mancio, M., Meral, C., Emwas, A. H., Mehta, P. K., \& Monteiro, P. J. M. (2014). High-volume natural volcanic pozzolan and limestone powder as partial replacements for portland cement in self-compacting and sustainable concrete. Cement and Concrete Composites, 45, 136-147. 
8. Chesner, W. H. (1988). The Ecosphere Recycling System and the Use of Glass as a Construction Aggregate Material. Solid Waste Management and Materials Policy. New York: Legislative Commission on Solid Waste.

9. Clean Washington Center (1993), Glass Feedstock Evaluation Project: Evaluation of Cullet as a Construction Aggregate, Report No. GL-93-6, Seattle, Washington.

10. Davidovits, J. (1994). Global Warming Impact on the Cement and Aggregates Industries, World Resource Review, 6(2), 263-278.

11. Dyer, T. D. and Dhir, R. K. (2001), Chemical reactions of glass cullet used as cement component, Journal of Materials in Civil Engineering, 13, 412-417.

12. Gibbs, M. J., Soyka, P. and Conneely, D. (2000). $\mathrm{CO}_{2}$ Emissions from Cement Production, Good Practice Guidance and Uncertainty Management in National Greenhouse Gas Inventories, Intergovernmental panel for climate change (IPCC).

13. Idir, R., Cyr, M., \& Tagnit-Hamou, A. (2011). Pozzolanic properties of fine and coarse color-mixed glass cullet. Cement and Concrete Composites, 33(1), 19-29.

14. IDOT (2016), Standard Specification for Road and Bridge Construction, Illinois Department of Transportation, Springfield, Illinois.

15. Islam, G. M. S., Rahman, M. H., and Kazi, N. (2017). Waste glass powder as partial replacement of cement for sustainable concrete practice, International Journal of Sustainable Built Environment, 6, 37-44.

16. Jani, Y. and Hogland, W. (2014), Waste glass in the production of cement and concrete - a review, Journal of Environmental Chemical Engineering, 2, 17671775 .

17. Metwally, I. M. (2007), Investigations on the performance of concrete made with blended finely milled waste glass, Advanced Structural Engineering, 10, 47-53.

18. Pereira-de-Oliveira, L. A., Castro-Gomes, J. P., and Santos, P. M. S. (2012), The potential pozzolanic activity of glass and red-clay ceramic waste as cement mortars components, Construction and Building Materials, 31, 197-203.

19. Peyvandi, A., Soroushian, P., \& Nassar, R.-U.-D. (2013). Recycled Glass Concrete, Concrete International, 35 (1), 29-32.

20. Shao, Y. and Leboux, P. (2001), Feasibility of using ground waste glass as a cementitious material, Recylcing and Resuse of Glass Cullet, Thomas Telford, Dundee, Scotland, United Kingdom, 210-219.

21. Shao, Y., Lefort, T., Moras, S., and Rodriguez, D. (2000), Studies on concrete containing ground waste glass, Cement and Concrete Research, 30, 91-100.

22. Shayan, A. and Xu, A. (2006), Performance of glass powder as a pozzolanic material in concrete: a field trial on concrete slabs, Cement and Concrete Research, 36, 457-468.

23. Shi, C., \& Zheng, K. (2007). A review on the use of waste glasses in the production of cement and concrete, Resources Conservation \& Recycling, 52(2), 234-247.

24. Shi, C., Wu, Y., Shao, Y. and Riefler, C. (2004). Alkali-aggregate reaction of concrete containing ground glass powder, Proceedings of the $12^{\text {th }}$ International Conference on AAR in Concrete, 789-795.

25. Taha, B. and Nounu, G. (2008), Properties of concrete containing mixed colour waste recycled glass as sand and cement replacement, Construction and Building Materials, 22, 713-720. 
26. Tao, J. (2017). Use of Crushed Recycled Glass in the Construction of Local Roadways Current Status of Recycled Glass Collection and Processing in the State of Ohio, Report No. FHWA/OH-2017-19, Ohio Department of Transportation, Columbus, Ohio.

27. Topcu, I. B. and Canbaz, M. (2004), Properties of concrete containing waste glass, Cement and Concrete Research, 34, 264-274.

28. USDOT (2016), User Guidelines for Waste and Byproduct Materials in Pavement Construction, Report Number: FHWA-RD-97-148, US Department of Transportation Federal Highway Administration, Washington, DC.

29. USEPA (2017). National Emission Standards for Hazardous Air Pollutants for the Portland Cement Manufacturing Industry and Standards of Performance for Portland Cement Manufacturing Industry: Residual Risk and Technology Review. Federal Register/Vol. 82, No. 182/ Thursday, Sept. 21, 2017/ p44254.

30. Wang, H. -Y., Zeng, H. -H., and Wu, J. -Y. (2014), A study on the macro and micro properties of concrete with LCD glass, Construction and Building Materials, 50, 664-670. 